\title{
Front Matter: Volume 8026
}

, "Front Matter: Volume 8026," Proc. SPIE 8026, Photonic Applications for Aerospace, Transportation, and Harsh Environment II, 802601 (5 July 2011); doi: $10.1117 / 12.899628$

SPIE Event: SPIE Defense, Security, and Sensing, 2011, Orlando, Florida, United SPIE. States 


\title{
PROCEEDINGS OF SPIE
}

\section{Photonic Applications for Aerospace, Transportation, and Harsh Environment II}

\author{
Alex A. Kazemi \\ Bernard Kress \\ Eric Y. Chan \\ Nabeel A. Riza \\ Lothar U. Kempen \\ Editors
}

25-26 April 2011

Orlando, Florida, United States

Sponsored and published by

SPIE 
The papers included in this volume were part of the technical conference cited on the cover and title page. Papers were selected and subject to review by the editors and conference program committee. Some conference presentations may not be available for publication. The papers published in these proceedings reflect the work and thoughts of the authors and are published herein as submitted. The publisher is not responsible for the validity of the information or for any outcomes resulting from reliance thereon.

Please use the following format to cite material from this book:

Author(s), "Title of Paper," in Photonic Applications for Aerospace, Transportation, and Harsh Environment II, edited by Alex A. Kazemi, Bernard Kress, Eric Y. Chan, Nabeel A. Riza, Lothar U. Kempen, Proceedings of SPIE Vol. 8026 (SPIE, Bellingham, WA, 2011) Article CID Number.

ISSN 0277-786X

ISBN 9780819486004

Published by

SPIE

P.O. Box 10, Bellingham, Washington 98227-0010 USA

Telephone +1 3606763290 (Pacific Time) · Fax +1 3606471445

SPIE.org

Copyright (C) 2011, Society of Photo-Optical Instrumentation Engineers

Copying of material in this book for internal or personal use, or for the internal or personal use of specific clients, beyond the fair use provisions granted by the U.S. Copyright Law is authorized by SPIE subject to payment of copying fees. The Transactional Reporting Service base fee for this volume is $\$ 18.00$ per article (or portion thereof), which should be paid directly to the Copyright Clearance Center (CCC), 222 Rosewood Drive, Danvers, MA 01923. Payment may also be made electronically through CCC Online at copyright.com. Other copying for republication, resale, advertising or promotion, or any form of systematic or multiple reproduction of any material in this book is prohibited except with permission in writing from the publisher. The CCC fee code is 0277-786X/11/ \$18.00.

Printed in the United States of America.

Publication of record for individual papers is online in the SPIE Digital Library.

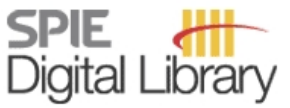

SPIEDigitalLibrary.org

Paper Numbering: Proceedings of SPIE follow an e-First publication model, with papers published first online and then in print and on CD-ROM. Papers are published as they are submitted and meet publication criteria. A unique, consistent, permanent citation identifier (CID) number is assigned to each article at the time of the first publication. Utilization of CIDs allows articles to be fully citable as soon as they are published online, and connects the same identifier to all online, print, and electronic versions of the publication. SPIE uses a six-digit CID article numbering system in which:

- The first four digits correspond to the SPIE volume number.

- The last two digits indicate publication order within the volume using a Base 36 numbering system employing both numerals and letters. These two-number sets start with $00,01,02,03,04$, $05,06,07,08,09,0 A, 0 B \ldots 0 Z$, followed by 10-1Z, 20-2Z, etc.

The CID number appears on each page of the manuscript. The complete citation is used on the first page, and an abbreviated version on subsequent pages. Numbers in the index correspond to the last two digits of the six-digit CID number. 


\section{Contents}

$\begin{array}{ll}\text { vii } & \text { Conference Committee } \\ \text { ix Introduction }\end{array}$

\section{SENSORS IN TRANSPORTATION/AEROSPACE APPLICATIONS}

802602 POF hydrogen detection sensor systems for launch vehicles applications (Invited Paper) [8026-01]

A. A. Kazemi, ARK International (United States) and The Boeing Co. (United States);

D. B. Larson, NexGen Research Corp. (United States); M. D. Wuestling, NexGen Research

Corp. (United States) and The Boeing Co. (United States)

802603 Viability of guided-wave ultrasound diagnostics for sharply curved composite structures [8026-02]

I. F. Saxena, N. Guzman, L. U. Kempen, Intelligent Optical Systems, Inc. (United States);

V. Dayal, lowa State Univ. (United States)

802604 Advances towards the qualification of an aircraft fuel tank inert environment fiber optic oxygen sensor system (Invited Paper) [8026-03]

E. A. Mendoza, Y. Esterkin, C. Kempen, S. Sun, Redondo Optics, Inc. (United States); K. Susko,

J. Goglia, Aviation Safety Facilitators (United States)

802605 Intrinsically safe oxygen and hydrogen optical leak detector [8026-04]

M. Beshay, S. Garon, D. Ruiz, L. U. Kempen, Intelligent Optical Systems, Inc. (United States)

\section{MICRO, NANO AND LASER PHOTONICS IN TRANSPORTATION}

802606 Miniaturized real-time monitor for fuel cell leak applications [8026-05]

M. Beshay, J. G. Chandra Sekhar, J. Delgado Alonso, C. Boehr, R. A. Lieberman, Intelligent Optical Systems, Inc. (United States)

802608 AUV-portable temperature-compensating fiber optic hydrophone [8026-07]

I. F. Saxena, N. Guzman, K. J. Hui, S. Pflanze, Intelligent Optical Systems, Inc. (United States)

8026 OA Linear polarizer local characterizations by polarimetric imaging for applications to polarimetric sensors for torque measurement for hybrid cars [8026-27]

F. Georges, M. Remouche, P. Meyrueis, Univ. de Strasbourg (France)

PHOTONICS IN HARSH ENVIRONMENT, SIGNAL PROCESSING

$8026 \mathrm{OB}$ Incoherent light guide imager for harsh and complex environments [8026-08]

L. R. Gauthier, Jr., The Johns Hopkins Univ. (United States) 
8026 OC Digital micromirror device-based robust object boundary mapping sensor [8026-09] P. J. Marraccini, CREOL, The College of Optics and Photonics, Univ. of Central Florida (United States); C. Baxley, Univ. of Central Florida (United States); N. A. Riza, CREOL, The College of Optics and Photonics, Univ. of Central Florida (United States)

8026 OD High resolution wide dynamic range distance sensor using spatial signal processing [8026-10]

P. J. Marraccini, N. A. Riza, CREOL, The College of Optics and Photonics, Univ. of Central Florida (United States)

8026 OE Multimode laser beam characterization using agile digital-analog photonics [8026-11] P. J. Marraccini, N. A. Riza, CREOL, The College of Optics and Photonics, Univ. of Central Florida (United States)

8026 OF Evanescent wave absorption measurements of corroded materials using ATR and optical fibers [8026-26]

J. Namkung, Naval Air Systems Command (United States); M. Hoke, Air Force Research Lab. (United States); A. Schwartz, Naval Air Systems Command (United States)

\section{ENVIRONMENTAL AND GAS MONITORING}

8026 OG Wireless/integrated strain monitoring and simulation system [8026-12]

F. Abdi, R. Dutton, T. Takahashi, C. Godines, G. Abumeri, AlphaSTAR Corp. (United States)

$8026 \mathrm{OH} \quad$ All optical $\mathrm{O} 2$ sensors using innovative phase fluorimetry for monitoring of headspace in ullage for FAA mandated inerting fuel tanks of commercial airlines [8026-13]

A. Panahi, ARK International (United States)

8026 OK Battery outgassing sensor for electric drive vehicle energy storage systems [8026-16] M. Beshay, J. G. Chandra Sekhar, L. U. Kempen, Intelligent Optical Systems, Inc. (United States)

\section{WIRLESS OPTICAL LINK, OPTICAL SATELLITE COMMUNICATION}

8026 OL High speed laser communication network for satellite systems [8026-17]

A. Panahi, A. A. Kazemi, ARK International (United States)

8026 OM Wireless optical links for avionics applications (Invited Paper) [8026-18]

E. Chan, D. Koshinz, W. Krug, H. Hager, The Boeing Co. (United States)

8026 ON Towards development of a fiber optic-based transmission monitoring system [8026-19] C. S. Baldwin, J. S. Kiddy, Aither Engineering, Inc. (United States); P. D. Samuel, Daedalus Flight Systems (United States)

802600 Review of optical fiber sensor technologies for hydrogen leak detection in hydrogen energy storage [8026-20]

C. Perrotton, N. Javahiraly, Univ. de Strasbourg (France); A. Kazemi, The Boeing Co. (United States); P. Meyrueis, Univ. de Strasbourg (France) 
VISION-BASED AND IMAGING SENSORS

8026 OP Speckle reduction technique for laser based automotive Head Up Display (HUD) projectors (Invited Paper) [8026-21]

B. Kress, V. Hejmadi, USI Photonics Inc. (United States)

$80260 Q$ Diffractive elements manufactured by grey tone mask and global laser lightning for transportation applications [8026-22]

F. Quentel, THALES (United Kingdom); K. Boehlen, Exitech Ltd. (United Kingdom); J. Fieret, A. Holmes, Imperial College London (United Kingdom); P. Meyrueis, V. Raulot, Univ. de Strasbourg (France)

Author Index 
Downloaded From: https://www.spiedigitallibrary.org/conference-proceedings-of-spie on 26 Apr 2023

Terms of Use: https://www.spiedigitallibrary.org/terms-of-use 


\title{
Conference Committee
}

\author{
Symposium Chair
}

William Jeffrey, HRL Laboratories, LLC (United States)

Symposium Cochair

Kevin P. Meiners, Office of the Secretary of Defense (United States)

Conference Chairs

Alex A. Kazemi, The Boeing Company (United States)

Bernard Kress, USI Photonics Inc. (United States)

Eric Y. Chan, The Boeing Company (United States)

Nabeel A. Riza, CREOL, The College of Optics and Photonics,

University of Central Florida (United States)

Lothar U. Kempen, Intelligent Optical Systems, Inc. (United States)

Program Committee

Frank Abdi, AlphaSTAR Corporation (United States)

Jacques Albert, Carleton University (Canada)

Christopher S. Baldwin, Aither Engineering, Inc. (United States)

Manal Beshay, Intelligent Optical Systems, Inc. (United States)

Ayoub Chakari, Ecole Nationale Supérieure de Physique de Strasbourg (France)

Fu-Kuo Chang, Stanford University (United States)

Dan Curticapean, Hochschule Offenburg (Germany)

James E. Fesmire, NASA Kennedy Space Center (United States)

Leo R. Gauthier, Jr., The Johns Hopkins University (United States)

Harold Hager, The Boeing Company (United States)

Zuyuan He, The University of Tokyo (Japan)

Robert G. Johnson, NASA Kennedy Space Center (United States)

Peter Kiesel, Palo Alto Research Center, Inc. (United States)

Dennis G. Koshinz, The Boeing Compnay (United States)

Edgar A. Mendoza, Redondo Optics, Inc. (United States)

Patrick P. Meyrueis, Ecole Nationale Supérieure de Physique de Strasbourg (France)

Jean-Pierre Moeglin, Institut Franco-Allemand de Recherches de Saint-Louis (France)

Ayman S. Mosallam, University of California, Irvine (United States)

Juock S. Namkung, Naval Air Warfare Center Aircraft Division

(United States)

Allen S. Panahi, Redondo Optics, Inc. (United States) 
Indu F. Saxena, Intelligent Optical Systems, Inc. (United States)

William St. Cyr, NASA Stennis Space Center (United States)

Pierre St. Hilaire, Holox Technologies, Inc. (United States)

\section{Session Chairs}

1 Sensors in Transportation/Aerospace Applications

Alex A. Kazemi, The Boeing Company (United States)

2 Micro, Nano and Laser Photonics in Transportation

Eric Y. Chan, The Boeing Company (United States)

3 Photonics In Harsh Environment, Signal Processing

Lothar U. Kempen, Intelligent Optical Systems, Inc. (United States)

$4 \quad$ Environmental and Gas Monitoring

Nabeel A. Riza, CREOL, The College of Optics and Photonics, University of Central Florida (United States)

5 Wirless Optical Link, Optical Satellite Communication

Indu F. Saxena, Intelligent Optical Systems, Inc. (United States) 


\section{Introduction}

Over the past forty years, the field of fiber optic sensors has undergone a remarkable change. Today a great proportion of the world's communications are carried by fiber optic cables. Fiber optic technology has revolutionized the telecommunication market and is rapidly becoming a major player in such areas as telephone, cable TV, and localarea network (LAN). It has spread into every situation in which information is being transmitted. Now even digital television is carried over fiber optic.

Fiber optic technology has gone through a quantum leap. I have been greatly impressed over the past few years by the tremendous progress in photonics in the transportation industry. More information, intelligence, and data are transferred from one point to another more quickly and precisely than ever thought possible, thanks to the miracle of optical fibers. Fiber optics shall become as common as wire, are easy to constructor to precise tolerances and are accurate and perfect in operation.

The fiber optic sensor greatly benefitted from the low-cost telecommunications industries, due to this synergy, an enormous amount of new technologies have been introduced in the form of smart sensor, biomedical sensors, pressure, temperature and liquid level, to name a few. In recent years, other optoelectronics industries such as lasers, which dominate the compact disk, DVD, laser printer, and scanner industry with the most promising users for lasers and communications over fiber optic cables. At the same time fiber optic sensor technology and photonics in transportation industry have developed in parallel with fiber optic.

I am fortunate to be among pioneers and the thrill of technical achievement can be just as tangible to those of us involved with engineering, technology, and science as the thrill of lifetime accomplishment. This book contains a series of papers which contains state-ofthe-art fiber optic sensor technologies for photonics in transportation industries such as advanced technologies for cryogenic leak detection of hydrogen and oxygen for space applications to a new generation of fiber optic media converter, high speed laser communication network for satellite systems and plastic optical fiber sensor for the harsh environment of space application.

On behalf of SPIE and myself, I would like to thank the individual authors for their valuable contributions, particularly Dr. Eric Chan of the Boeing Co., Dr. Allen Panahi of ARK International, Prof. Patrick Meryueis of the University of Strasbourg, Prof. Nabeel Riza of CREOL, of the University of Central Florida, Dr. Lothar Kempen, Dr. Ed Mendoza, and Dr. Bernard Kress of USI Photonics, Inc. for outstanding papers they presented in this book. I would also like to thank my wife for her support during this conference.

Alex A. Kazemi 
Downloaded From: https://www.spiedigitallibrary.org/conference-proceedings-of-spie on 26 Apr 2023

Terms of Use: https://www.spiedigitallibrary.org/terms-of-use 